\section{Hazardous wastes}

\section{Give US laboratories a break}

\section{Washington}

WASTE-disposal procedures in US laboratories should be greatly simplified, according to a National Academy of Sciences study that has just been published. The recommendations are a response to the frustrations felt by researchers in trying to comply with the present complicated federal regulations governing the disposal of hazardous waste.

The regulations which have been in effect since 1980 were designed to halt the haphazard and back-door methods of disposing of hazardous substances that came to public attention through such notorious cases as the "Valley of the Drums", where thousands of corroding 55-gallon steel drums had been dumped. The problem, says Dr Robert Alberty of Massachusetts Institute of Technology, the chairman of the academy study, is that the regulations were designed primarily with industry, not laboratories in mind. Speaking at last week's American Chemical Society meeting, Alberty said that the rules place a burden on laboratories "out of proportion to the fraction of hazardous waste that laboratories generate and to the overall hazard it poses",

According to estimates by the Environmental Protection Agency (EPA), laboratories account for only $0.1-1$ per cent of the waste defined as "hazardous" under the present regulations. These include toxic, corrosive, combustible and reactive chemicals. Radioactive wastes are covered by a different set of rules.

The hazardous waste regulations require that each producer of waste keep extensive records of each specific hazardous chemical generated and that a system of shipping manifests be used to ensure that waste is delivered properly to an approved landfill or disposal facility. Laboratories tend to produce small quantities of a great many different substances, which can result in a particularly onerous record-keeping burden. Even a collection of used filter paper, residues of chromatographic separations and minor by-products from smallscale tests would have to be listed, by specific chemical content, on a shipping manifest for disposal. "No useful purpose is served by listing what may be more than 100 individual small samples" the academy study says.

Instead, the study recommends that wastes from laboratories be labelled, and records kept, only in terms of seven broad categories: reactive, toxic, ignitable, acidic, basic, oxidizers and a miscellaneous category for the filter-paper and crustytest-tube sort of trace quantity waste. A drum containing laboratory wastes so identified could be shipped to a disposal site, the study proposes, so long as no containers in the drum were larger than 20 litres.

The study also criticizes the existing

\section{Radioactive waste}

regulations for effectively forcing laboratories to use landfills rather than incineration for disposing of waste. Although incineration is potentially safer and more convenient than landfill disposal, commercial incinerators usually refuse to accept

\title{
UK ocean dumping in dispute
}

GREENPEACE, the "direct action" environmentalist organization, has stepped up its campaign to embarrass the British Government over dumping of low-level radioactive waste in the sea. Greenpeace has released copies of a restricted government document which, it is claimed, indicates that the Ministry of Defence (MoD) is secretly planning to include in the scheduled 1984 dump in the Atlantic plutoniumcontaining wastes from the Atomic Weapons Research Establishment at Aldermaston.

Friends of the Earth, the more sedentary but equally vocal UK environmental group which has been campaigning for more freedom of information, congratulated the unnamed public servant who leaked the document for bringing the affair into the public eye. The document consists of minutes of a meeting between representatives of MoD and the Ministry of Agriculture, Fisheries and Food. Although the

\section{Medal invented}

\section{Washington}

THOse who accuse President Reagan of favouring form over substance were recently handed some new ammunition. Having apparently decided that its plan to reorganize the Department of Commerce was not enough to stimulate technological productivity (even if the new name - the Department of International Trade and Industry - would make everyone think of Japan's awe-inspiring Ministry of International Trade and Industry), the administration has now come up with a new presidential medal.

"The President is eager to recognize innovators in technology who have helped America compete successfully in the international market place"', said George Keyworth, the President's science adviser, in announcing the new National Medal of Technology. Nominations will be accepted by the Department of Commerce until November $30^{*}$. To help nominators, the White House offered this pointer: "Had the medal existed in the past, it might have gone to Thomas Edison for initiating urban electrification." Stephen Budiansky "Instructions and nomination forms are available from: Assistant Secretary for Productivity, Technology, and Innovation, US Department of Commerce, Washington, DC 20230. laboratory waste because of the small quantities and great chemical diversity. The study says that installation of small incinerators at laboratory sites could be encouraged by waiving the expensive requirement for a test burn before a licence can be granted. The academy study recommends that EPA should adopt a conservative design standard as a substitute for the test burn requirement. Stephen Budiansky minutes do not describe MoD's proposal in detail, it appears that the plan was to dump waste containing between 200 and 600 grams of plutonium in 4 or 5 containers. Much of the discussion at the meeting centred on whether the proposed containers, which are larger than the type used for most low-level waste, would "attract attention" and "lead to awk ward questions about the contents and origin of the packages".

MoD says that no decision has yet been taken on the plan, but that the waste would certainly come within the Internationa Atomic Energy Authority's (IAEA's) definition of low-level waste suitable for sea dumping. For alpha-emitters, the limit is 1 curic per ton averaged over 1,000 tons. Independent authorities confirm that, with suitable dilution and making certain assumptions about the isotopic composition, this quantity of plutonium could easily be packaged so as to come within the IAEA definition. The activity of the waste is estimated to be in the region of 30 curies, which is less than 3 per cent of the alphacuries dumped by Britain in 1982 . Grcenpeace's claim that the proposal would "defy all international regulations" therefore seems difficult to sustain.

Last February, the London Dumping Convention adopted by 19 votes to 6 (with 5 abstentions) a resolution calling for all sea dumping of radioactive materials to be suspended pending an expert report which will be available for the convention's 1985 meeting. The resolution, which is not legally binding, stemmed from a proposal from two Pacific nations, Kiribati and Nauru; the countries that voted against were Britain, the United States, Japan, the Netherlands, South Africa and Switzerland. After the convention meeting, Britain announced that it would proceed with plans to dump 4,000 tons of low-level waste this summer. Britain accounts for about 80 per cent of all nuclear waste dumped at sea. In the event, the British plans appear to have been thwarted by industrial action by the National Union of Seamen, supported by several other transport unions. The union's executive instructed its members to black the cargo, and the dumping vessel, Atlantic Fisher, has not yet sailed. NIREX, the nuclear waste disposal executive, is now looking for suitable land dumping sites.

Tim Beardsley 